\title{
A Nationwide Study of Norwegian Beliefs About Same-sex Marriage and Lesbian and Gay Parenthood
}

\author{
Ragnhild Hollekim • Hilde Slaatten • Norman Anderssen
}

Published online: 21 April 2011

(C) The Author(s) 2011. This article is published with open access at Springerlink.com

\begin{abstract}
In Norway, a gender-neutral Marriage Law that secured equal marriage and parenting rights for lesbian, gay and heterosexual couples took effect in January 2009. The aim of the current study was to explore Norwegian beliefs about equal marriage and parenting rights for lesbian, gay and heterosexual couples and the welfare of children with lesbian and gay parents. A sample of 1,246 Norwegians participated in the study by filling out a questionnaire. The majority reported that they were supportive of equal marriage rights for lesbian, gay and heterosexual couples, whilst there was less support for granting gay and lesbian couples equal right to become parents. The negative attitudes towards equal parenting rights for lesbian, gay and heterosexual couples were explained mainly by concerns about the welfare of children growing up with gay and lesbian parents.
\end{abstract}

Keywords Same-sex marriage · Lesbian · Gay · Parenting · Law · Children · Rights · Public opinion · Homosexuality · Norway

R. Hollekim $(\bowtie) \cdot$ H. Slaatten

Research Centre for Health Promotion, University of Bergen,

Christies gt 13,

5020 Bergen, Norway

e-mail: ragnhild.hollekim@psybv.uib.no

H. Slaatten

e-mail: Hilde.Slatten@iuh.uib.no

H. Slaatten $\cdot N$. Anderssen

Department of Psychosocial Science, University of Bergen,

Christiesgt 12,

5020 Bergen, Norway

N. Anderssen

e-mail: Norman.Anderssen@psysp.uib.no

\section{The Norwegian Gender-Neutral Marriage Law}

In Norway, a gender-neutral Marriage Law took effect from 1 January 2009, replacing a Law on Registered Partnership that was introduced in 1993 (Ministry of Children, Equality and Social Inclusion 2009a, b). The new law secured equal marriage and parenting rights for lesbian, gay and heterosexual couples, including the right to apply for adoption. Lesbian couples were granted the right to be assessed for state-sponsored artificial insemination procedures and comotherhood could be given to the spouse of the biological mother. The Norwegian state church and other religious communities in Norway retained reservation rights in relation to church weddings. Ministers and priests were given the right, but not the obligation, to perform wedding ceremonies for same-sex couples (Ministry of Children, Equality and Social Inclusion 2009a, b). This article reports findings from a nationwide study investigating Norwegian beliefs about equal marriage and parenting rights for lesbian, gay and heterosexual couples and the welfare of children with lesbian and gay parents.

In Norway, there has been a series of changes in the legal status of homosexuals since the removal of male homosexuality from the Criminal Code in 1972. Twenty years later, when the Law on Registered Partnership was introduced, lesbian and gay couples were at large granted the same legal rights as heterosexual couples except for church weddings, joint adoption and statesponsored assisted fertilization (Halvorsen 1998). The new Marriage Law of 2009, on the other hand, introduced progressive legislation regarding such rights, and it makes no distinction based on gender, except for reservation rights in relation to church weddings. Today, Norway is considered one of the most liberal countries in the world with regard to securing equal legal rights for heterosexuals 
and homosexuals (Anderssen and Hellesund 2009; Badgett 2004) and was the first among the Nordic countries to introduce a gender-neutral Marriage Act. This makes Norway an interesting case to study more closely.

The public debate in the period leading up to Norway's new gender-neutral Marriage Law covered a spectrum of topics related to marriage rights for same-sex couples, but mainly centred on lesbian and gay parenthood (Folgerø, 2008) and whether it was in the child's best interest to grant lesbian and gay couples the right to become parents. Opponents of the new Marriage Law argued that the proposal was not in agreement with the best interests of the child and that lesbian and gay rights (adult rights) were given priority over children's rights. The viewpoint that growing up with lesbian and gay parents would place an extra strain or burden on the child was further promoted. Biological bonds and a heterosexual nuclear family with both male and female role models were believed to be prerequisites for a healthy environment for children (Anderssen and Hellesund 2009; Folgerø 2008; Proposition nr. 33 2007-2008). Supporters of the proposal, on the other hand, emphasized an equal rights and a justice perspective. They argued that the gender-neutral Marriage Law would facilitate freedom from discrimination for children raised in lesbian and gay relationships whilst in general preventing prejudiced and moralizing notions concerning lesbian and gay parenting and children growing up with lesbian and gay parents. Supporters further expressed a belief that a parent's sexual orientation is not related to her/his ability to provide a healthy and nurturing environment for children (Folgerø 2008; Proposition nr. 33 2007-2008). Conversely, various groups argued that there had been insufficient research into the consequences for children following provisions for equal parenting rights for lesbian, gay and heterosexual couples in the new gender-neutral Marriage Law and that these had not received adequate consideration. A similar division of opinions and arguments between supporters and opponents have also been identified in the public debate in other countries where questions such as legal recognition of marriage and parenting rights for lesbian and gay couples have been on the political agenda, such as in the USA, France and Sweden (Eskridge 2001; Government Commission 2006; Pew Research Center 2009; Price et al. 2005).

At present, same-sex marriage is legal in countries including the Netherlands, Belgium, Canada, Spain, South Africa, Norway, Sweden, Iceland, Portugal, Argentina and only a few states in the USA, whereas same-sex couples may register as partners or have rights to a form of civil union in a number of other countries (ILGA-Europe 2009; Peel and Harding 2008). Few countries grant equal parenting rights to lesbian, gay and heterosexual couples (ILGA-Europe 2009).

\section{Beliefs About Same-Sex Marriage Rights}

Support appears to be increasing for the legalizing of samesex partnerships through civil unions and, in some Western societies, through marriage (Graham 2004; Herek 2006; Badgett 2004). However, population support for same-sex marriage rights has been studied mainly through polls that generally contain a single-item question only. The phrasing of the item varies somewhat, making comparison between countries challenging. In 2005, two Norwegian polls found that $60 \%$ (Dagsavisen 2005) and 63\% (Klassekampen 2005) of respondents supported equal marriage rights for lesbian, gay and heterosexual couples. A year later, a European poll found that $66 \%$ of Norwegian respondents, $69 \%$ of Swedish respondents and $71 \%$ of Danish respondents supported same-sex marriage rights (European Commission 2006). In 2006, on average, $44 \%$ of the European Union (EU) population supported such rights (European Commission 2006). Recent polls from the USA indicate that between $35 \%$ and $39 \%$ of the population support samesex marriage rights at present (People Press Organization 2009; Pew Forum 2009).

\section{Beliefs About Equal Parenting Rights}

In Europe, granting equal parenting rights for lesbian, gay and heterosexual couples have generally been more contested than the question of securing legal recognition of same-sex partnership. In 2000, the Council of Europe claimed that it was too early to give recommendations concerning lesbian and gay parenthood. A majority of the Council of Europe's Committee on Legal Affairs and Human Rights stated that in questions concerning lesbian and gay parenthood, the child's interests must override all other concerns. Lesbian and gay couples were not considered in the best position to satisfy these interests (Swedish Official Report 2001). At the same time, they recommended that all member states should facilitate legal registration for same-sex partners. In a literature review on discrimination of lesbian, gay, bisexual and HIV-positive persons in Norway, Danielsen (2005) demonstrated that Norwegian legislation at that time could be interpreted in a way that society did not want lesbian and gay couples to care for children. Uncertainty about whether lesbian and gay parenthood was in the child's best interest was considered the decisive issue when a French Parliamentary Committee refused to support a proposal for gender-neutral marriage legislation in France in 2006. The proposal was rejected mainly because gender-neutral marriage legislation automatically would imply equal parenting rights for lesbian, gay and heterosexual couples (Government Commission 2006). 
In $1998,25 \%$ of the Norwegian population supported adoption rights for lesbian and gay couples, whilst a clear majority was against it (MMI 1998). Representative surveys from Sweden and the USA show that approximately two thirds of the population was against giving lesbian and gay couples adoption rights (Herek 2002; Landèn and Innala 2002). Findings from European polls further support an apparently less tolerant attitude towards equal parenting rights than equal marriage rights for same-sex couples. In 2006, 44\% of Danish respondents, $51 \%$ of Swedish respondents and $32 \%$ of the overall EU population generally supported adoption rights for lesbian and gay couples (European Commission 2006), whilst the support for lesbian and gay adoption rights among the US population was 46\% (People Press Organization 2009). In general, average public opinion in Europe seems to reflect a more tolerant attitude towards same-sex marriages than to legal provisions to secure equal adoption rights for lesbian and gay couples, whilst in the USA, more people support adoption rights for lesbian and gay couples than marriage rights.

\section{Demographics Related to Attitudes Towards Equal Marriage and Parenting Rights}

Demographics have been studied more in relation to marriage than parenting rights. This research shows that being male, older, less educated, more religious and politically/ideologically more conservative (for example in relation to political affiliation, views on gender roles) predict more negative attitudes towards equal marriage rights (Brumbaugh et al. 2008; Pearl and Galupo 2007; Olson et al. 2006; EOS Gallup Europe 2003). However, there are some indications that the same predictors predict negative attitudes towards equal parenting rights (e.g. EOS Gallup Europe 2003; Hicks and Lee 2006).

\section{Beliefs About the Welfare of Children with Lesbian and Gay Parents}

According to Herek (2006), concerns about the welfare of children with lesbian and gay parents, and their needs and interests with respect to lesbian and gay parenthood, have always been an integral part of the debate on equal marriage rights for lesbian and gay couples. This was also the case in the Norwegian debate surrounding the genderneutral Marriage Law (see above). In 1998, between 41\% and $48 \%$ of the Norwegian population believed that children will be harmed growing up with lesbian and gay parents (MMI 1998). A recent Australian study by Morse et al. (2008), investigating population attitudes towards lesbian and gay parents and projected outcomes for their children $(n=1,217)$, found that lesbian and gay parents were consistently rated less favourably than heterosexual parents across variables such as nurturing ability and suitability as role models. The study further indicated that "participants believed that children raised by gay male and lesbian parents would be more likely to experience confusion over their gender identity and sexual orientation, be homosexual, experience strained peer relationship, stigma and teasing" (p. 436). Despite growing empirical evidence that children with lesbian and gay parents do as well as other children on important social and psychological outcomes (see metaanalyses by Crowl et al. 2008; Biblarz and Stacey 2010), Biblarz and Stacey (2010) claim that there is a widespread popular conviction concerning the supremacy of heterosexual parents for successful parenting.

\section{Research Questions}

There is limited research-based knowledge about how the general population views marriage and parenting rights for lesbian women and gay men and the welfare of children with lesbian and gay parents. This paper presents findings from a nationwide study of Norwegian beliefs about equal marriage and parenting rights for lesbian, gay and heterosexual couples and the welfare of children with lesbian and gay parents. Each of the three topics (marriage rights, parenting rights and the welfare of children with lesbian and gay parents) deserves exploration in its own right and will be addressed. Equal parenting rights for lesbian, gay and heterosexual couples seem, however, to be the most contested idea in a European as well as in a Norwegian context, and we have chosen this as the dependent variable to explore more specifically.

\section{Methods}

Participants

The sample consists of 1,246 participants, 614 (49\%) males and $632(51 \%)$ females, aged from 16 to 80 years. Mean age was 45 years $(\mathrm{SD}=17)$. Forty per cent of the participants lived in an area with $<20,000$ inhabitants and $37 \%$ lived in an area with more than 100,000 inhabitants. The sample composition generally reflects the demographic profile of Norway. Participants with higher education are, however, overrepresented. In the present sample, $57 \%$ of the participants reported that they have a university/college degree, whereas only $29 \%$ of the general population who are 16 years or above are reported to have a university/ college degree (Statistics Norway 2010a, b). 


\section{Measures}

The authors developed the measures based on polls regarding lesbian and gay marriage and parenting and relevant items from research on attitudes towards lesbian and gay people. The questionnaire was piloted twice: in a sample of students $(n=207)$ and in sample of students and employees in a private company $(n=192)$. Few studies have, however, studied the themes in depth. Each item was phrased according to contemporary Norwegian laws and context. ${ }^{1}$ The pilot studies displayed high face validity. Items are presented below and in the tables.

\section{Beliefs About Equal Marriage Rights for Lesbian, Gay and Heterosexual Couples}

These were assessed by three statements about marriage rights for same-sex couples (see Table 1). For each statement, the response alternatives were "Completely agree", "Slightly agree", "Neither agree nor disagree", "Slightly disagree", "Completely disagree" and "Uncertain". Responses to the three statements were summed to create the scale "Beliefs about equal marriage rights for lesbian, gay and heterosexual couples", with high scores indicating positive attitudes towards such rights. The scale had a Cronbach's alpha of 0.89. For the analysis, the response alternative "Uncertain" was recoded as a missing variable.

\section{Beliefs About Equal Parenting Rights for Lesbian, Gay and Heterosexual Couples}

These were assessed by six statements about equal rights to become parents through adoption and state-sponsored artificial insemination (see Table 2). Responses to the six statements were summed to create the scale "Beliefs about equal parenting rights for lesbian, gay and heterosexual couples", with high scores indicating positive attitudes towards such rights. The scale had a Cronbach's alpha of 0.96. Instructions and response alternatives were the same as for the statements concerning marriage rights (see above). For the analysis, the response alternative "Uncertain" was recoded as a missing variable. Respondents who

\footnotetext{
${ }^{1}$ The questionnaire utilized various descriptive phrases regarding sexual orientation, gender, couples and parenting to stay close to typical phrases and conceptualizations in Norway today. These were "same-sex couples", "lesbian and gay couples", "heterosexual couples", "lesbian and gay parents" and "heterosexual parents". Lesbian and gay parents are not necessarily same-sex parents, and same-sex parents are not necessarily lesbian or gay. However, the questionnaire was introduced and framed as a survey on attitudes towards various sexualities, and the most common terms were lesbian, gay, and heterosexual. In the presentation of results and discussion, we utilize these terms as close to the questionnaire items as possible.
}

reported that they were opposed to granting lesbian and gay couples parenting rights on at least five out of six statements were classified as "Negative to equal parenting rights", whereas respondents who supported equal parenting rights on at least five out of six statements were classified as "Positive to equal parenting rights". The remaining participants were classified as "Overall neither very positive nor very negative". Three additional questions investigated whether participants supported gay men's use of surrogacy abroad and whether regulated forms of egg donation and surrogacy should be made legal in Norway.

\section{Beliefs About the Welfare of Children with Lesbian and Gay} Parents

These were assessed by eight statements (see Table 3). Four items expressed positive beliefs and four items expressed concerns about the welfare of children with lesbian and gay parents. The eight items were summed to form the scale "Beliefs about the welfare of children with lesbian and gay parents", with high scores indicating concern for the children's welfare. The scale had a Cronbach's alpha of 0.92. Instructions and response alternatives were the same as for the statements concerning marriage rights (see above). For the analysis, the response alternative "Uncertain" was recoded as a missing variable.

\section{Demographics}

These included gender, age, population density, education, parental status, political affiliation and religious faith. Population density was measured by an item about the number of inhabitants in the current place of residence (Hegna et al. 1999). Education was assessed by asking participants about the highest educational level they achieved. Descriptions of the response alternatives for education and population density are shown in Table 4. Parental status was assessed by asking the participants how many children they have. Political affiliation was assessed by asking the participants which party they would vote for if there were a general election tomorrow. For the analysis, the parties were recoded as "Social democratic/Socialist parties" or "Center/Right parties". Religious faith was operationalized by the question: "If you think about your relationship to the religion you belong to, where would you place yourself?" (Anderssen 2002). Response alternatives ranged from 1 (Not believing) to 7 (Believing). Response alternatives 1 and 2 were coded as "No or low faith", response alternatives 3 to 5 were coded as "Some faith", and response alternatives 6 and 7 were coded as "High faith". For all background questions, the participants were able to respond that they did not wish to answer. These response alternatives were recoded as missing for the data analysis. 
Table 1 Beliefs about equal marriage rights for lesbian, gay and heterosexual couples

\begin{tabular}{|c|c|c|c|c|c|c|c|c|c|}
\hline & \multicolumn{2}{|c|}{ Agree, $n(\%)$} & \multicolumn{2}{|c|}{$\begin{array}{l}\text { Neither agree nor } \\
\text { disagree, } n(\%)\end{array}$} & \multicolumn{2}{|c|}{ Disagree, $n(\%)$} & \multicolumn{2}{|c|}{ Uncertain, $n(\%)$} & \multirow[t]{2}{*}{$\chi^{2}$} \\
\hline & Males & Females & Males & Females & Males & Females & Males & Females & \\
\hline $\begin{array}{l}\text { Same-sex couples should have the } \\
\text { same legal rights to have a civil } \\
\text { wedding as heterosexual couples }\end{array}$ & $378(58)$ & $461(78)$ & $78(12)$ & $37(6)$ & $186(29)$ & $75(13)$ & $11(2)$ & $20(3)$ & $69.9 *$ \\
\hline $\begin{array}{l}\text { Same-sex couples should have the } \\
\text { same legal rights to have a church } \\
\text { wedding as heterosexual couples }\end{array}$ & $246(38)$ & $391(66)$ & $104(16)$ & $54(9)$ & 287 (44) & $119(20)$ & $16(3)$ & $29(5)$ & $119.5^{*}$ \\
\hline $\begin{array}{l}\text { Marriage as an institution should be } \\
\text { reserved for a man and a woman }\end{array}$ & $300(46)$ & $125(21)$ & $79(12)$ & $69(13)$ & 254 (39) & $370(62)$ & $20(3)$ & $29(5)$ & $93.3^{*}$ \\
\hline
\end{tabular}

$* p<0.01$

\section{Design and Procedure}

The present analysis is based on data from the study "Norwegian attitudes towards LBGT persons 2008" (Anderssen and Slåtten 2008) collected in April and May 2008. Information from participants was collected through a web-based survey. Participants were drawn from a database of 75,000 individuals, administered by Norstat (a provider of data collection), consisting of persons who have agreed to participate in online surveys. Through the poll institute Opinion AS, a national stratified sample based on age, gender and regions was established. Participants were continuously and randomly recruited by Norstat until the needed number in each stratified group was complete. The number of people who disagreed to participate during this process is not known. In 2009, $86 \%$ of Norwegian inhabitants between the ages of 9 and 79 years had access to the Internet at home (Statistics Norway 2010a, b).

\section{Data Analysis Plan}

Frequency analysis was used to display attitudes towards marriage and parenting rights and beliefs about the welfare of children with gay and lesbian parents. For presentation of the individual items, the response alternatives

Table 2 Beliefs about equal parenting rights for lesbian, gay and heterosexual couples

\begin{tabular}{|c|c|c|c|c|c|c|c|c|c|}
\hline & \multicolumn{2}{|c|}{ Agree, $n(\%)$} & \multicolumn{2}{|c|}{$\begin{array}{l}\text { Neither agree nor } \\
\text { disagree, } n(\%)\end{array}$} & \multicolumn{2}{|c|}{ Disagree, $n(\%)$} & \multicolumn{2}{|c|}{ Uncertain, $n(\%)$} & \multirow[t]{2}{*}{$\chi^{2}$} \\
\hline & Males & Females & Males & Females & Males & Females & Males & Females & \\
\hline $\begin{array}{l}\text { Lesbian couples should have the same } \\
\text { legal rights as heterosexual couples to } \\
\text { apply for adoption }\end{array}$ & $246(40)$ & $387(61)$ & $73(12)$ & $57(9)$ & $270(44)$ & $167(26)$ & $26(4)$ & $21(3)$ & $80.9^{*}$ \\
\hline $\begin{array}{l}\text { Gay couples should have the same legal } \\
\text { rights as heterosexual couples to apply } \\
\text { for adoption }\end{array}$ & $222(36)$ & $363(57)$ & $71(12)$ & $81(13)$ & 298 (49) & 169 (27) & $23(4)$ & $19(3)$ & $98.2 *$ \\
\hline $\begin{array}{l}\text { Lesbian couples should be given the } \\
\text { same legal rights as heterosexual } \\
\text { couples to receive artificial } \\
\text { insemination }\end{array}$ & $210(34)$ & $323(51)$ & $101(17)$ & $83(13)$ & $273(44)$ & $200(32)$ & $30(5)$ & $26(4)$ & $58.3^{*}$ \\
\hline $\begin{array}{l}\text { After birth through artificial } \\
\text { insemination, automatic co- } \\
\text { motherhood should be given to the } \\
\text { spouse of the biological mother }\end{array}$ & 209 (34) & $332(53)$ & $126(21)$ & $129(20)$ & $224(37)$ & $114(18)$ & $56(9)$ & $57(9)$ & $65.7^{*}$ \\
\hline $\begin{array}{l}\text { Only heterosexual couples should be } \\
\text { allowed to receive artificial } \\
\text { insemination }\end{array}$ & $275(45)$ & $182(29)$ & $101(16)$ & $87(14)$ & 209 (34) & $324(51)$ & $30(5)$ & $39(6)$ & $67.2 *$ \\
\hline $\begin{array}{l}\text { The right to apply for adoption should } \\
\text { be independent of sexual orientation }\end{array}$ & 237 (39) & $388(61)$ & $81(13)$ & $60(10)$ & $277(45)$ & $163(26)$ & $20(3)$ & $21(3)$ & $88.4^{*}$ \\
\hline
\end{tabular}

$* p<0.01$ 
Table 3 Beliefs about the welfare of children with lesbian and gay parents

\begin{tabular}{|c|c|c|c|c|c|c|c|c|c|}
\hline & \multicolumn{2}{|c|}{ Agree, $n(\%)$} & \multicolumn{2}{|c|}{$\begin{array}{l}\text { Neither agree nor } \\
\text { disagree, } n(\%)\end{array}$} & \multicolumn{2}{|c|}{ Disagree, $n(\%)$} & \multicolumn{2}{|c|}{ Uncertain, $n(\%)$} & \multirow[t]{2}{*}{$\chi^{2}$} \\
\hline & Males & Females & Males & Females & Males & Females & Males & Females & \\
\hline $\begin{array}{l}\text { Society is now ready for children } \\
\text { growing up with lesbian/gay parents }\end{array}$ & $199(32)$ & $305(48)$ & $127(21)$ & $114(18)$ & $248(40)$ & $169(26)$ & $40(7)$ & $43(7)$ & $48.0^{*}$ \\
\hline $\begin{array}{l}\text { Children who grow up with lesbian } \\
\text { mothers or gay fathers are more } \\
\text { often exposed to bullying } \\
\text { (systematic bothering) than } \\
\text { other children }\end{array}$ & $305(50)$ & $230(37)$ & $147(24)$ & $200(32)$ & $75(12)$ & $94(15)$ & 87 (14) & 107 (17) & $18.0^{*}$ \\
\hline $\begin{array}{l}\text { Children are harmed by growing up } \\
\text { with two lesbian women as mothers }\end{array}$ & $145(24)$ & $67(11)$ & $147(24)$ & $123(19)$ & $271(44)$ & $401(64)$ & $51(8)$ & $41(7)$ & $57.7 *$ \\
\hline $\begin{array}{l}\text { Children are harmed by growing up } \\
\text { with two gay men as fathers }\end{array}$ & $173(28)$ & $82(13)$ & $141(23)$ & $115(18)$ & 237 (39) & $384(61)$ & $62(10)$ & $50(8)$ & $69.9^{*}$ \\
\hline $\begin{array}{l}\text { Children who grow up with lesbian } \\
\text { women are just as well off as other } \\
\text { children }\end{array}$ & $257(42)$ & $389(62)$ & $176(29)$ & $140(22)$ & 114 (19) & $51(8)$ & $67(11)$ & $52(8)$ & $56.0^{*}$ \\
\hline $\begin{array}{l}\text { Children who grow up with gay } \\
\text { fathers are just as well off as other } \\
\text { children }\end{array}$ & $217(35)$ & $367(58)$ & $178(29)$ & $150(24)$ & $138(22)$ & $61(10)$ & $81(13)$ & $54(9)$ & $78.8^{*}$ \\
\hline $\begin{array}{l}\text { Children's needs and interests can be } \\
\text { fully met by lesbian/gay parents }\end{array}$ & $311(51)$ & $444(70)$ & $109(18)$ & $81(13)$ & $163(27)$ & $77(12)$ & $32(5)$ & $30(5)$ & $72.5^{*}$ \\
\hline $\begin{array}{l}\text { Sexual orientation does not matter for } \\
\text { good parenting }\end{array}$ & $297(48)$ & 437 (69) & $125(20)$ & 97 (15) & $153(25)$ & $68(11)$ & $38(6)$ & $29(5)$ & $66.7^{*}$ \\
\hline
\end{tabular}

$* p<0.01$

"Completely agree" and "Slightly agree" were recoded as "Agree", whilst "Slightly disagree" and "Completely disagree" were recoded as "Disagree". Chi-square tests were used to determine whether male and female respondents held different attitudes and beliefs concerning these matters. Cross-tabulations were used to analyse selected background variables, including chi-square analyses of distributions for men and for women for each background variable. A hierarchical multiple regression analysis was conducted to examine predictors of the variable "Beliefs about equal parenting rights for lesbian, gay and heterosexual couples" (sum score of full scale). Due to multicollinearity ( $r=-0.73$, see Table 5 ) between the two scales "Beliefs about equal marriage rights for lesbian, gay and heterosexual couples" (full score) and "Beliefs about the welfare of children with lesbian and gay parents" (full score), we excluded the former. For statistical analysis, the response alternative "Uncertain" was recoded as missing (see above). Whereas the response alternative "Neither agree nor disagree" can be given a score which soundly fits between "Agree" and "Disagree", the response alternative "Uncertain" is more problematic. This response category could potentially mean that the participants have not made up their mind yet. As it is hard to quantify the "Uncertain" variable in any direction, we chose to treat this variable as missing. The SPSS programme version 15 was used for the statistical analysis (Pallant 2007).

\section{Results}

\section{Beliefs About Equal Marriage Rights}

A clear majority of women and men supported equal civil marriage rights for lesbian, gay and heterosexual couples. More women than men were positive. However, both genders were more sceptical towards granting gay and lesbian couples the right to have church rather than civil weddings (see Table 1).

\section{Beliefs About Equal Parenting Rights}

Overall, more than half the women and more than a third of men reported that they were in favour of granting gay and lesbian couples the same parenting rights as heterosexual couples (see Table 2). More men than women further reported that they believed the legal system should not be changed to facilitate gay and lesbian couples becoming parents. A substantial proportion reported that they neither agreed nor disagreed, or that they were uncertain whether they thought gay and lesbian couples should be granted the same legal rights to become parents as heterosexual couples.

More women (42\%) than men (25\%) reported that they thought gay men should be allowed to use legal surrogacy arrangements abroad and that egg donation (women, 62\%; men, $50 \%$ ) and surrogacy in regulated forms (women, $44 \%$; 
Table 4 Beliefs about equal parenting rights, and for lesbian, gay and heterosexual couples being granted the same legal rights to become parents as heterosexual couples, stratified by selected background variables

\begin{tabular}{|c|c|c|c|c|c|c|}
\hline & \multicolumn{2}{|l|}{ Negative $^{a}$} & \multicolumn{2}{|c|}{$\begin{array}{l}\text { Overall neither very positive } \\
\text { nor very negative }\end{array}$} & \multicolumn{2}{|l|}{ Positive $^{b}$} \\
\hline & Males, $\%(n / N)$ & Females, $\%(n / N)$ & Males, $\%(n / N)$ & Females, $\%(n / N)$ & Males, \% $(n / N)$ & Females, $\%(n / N)$ \\
\hline Total sample & $42(238 / 572)$ & $20(100 / 513)$ & $28(161 / 572)$ & $27(136 / 513)$ & $30(173 / 572)$ & $54(277 / 513)$ \\
\hline \multicolumn{7}{|l|}{ Age (years) } \\
\hline $15-20$ & $6(2 / 32)$ & $7(4 / 55)$ & $53(17 / 32)$ & $31(17 / 55)$ & $41(13 / 32)$ & $62(34 / 55)$ \\
\hline $21-30$ & $31(16 / 52)$ & $13(16 / 120)$ & $27(14 / 52)$ & $26(31 / 120)$ & $42(22 / 52)$ & $61(73 / 120)$ \\
\hline $31-40$ & $37(21 / 57)$ & $24(31 / 129)$ & $26(15 / 57)$ & $16(20 / 129)$ & $37(21 / 57)$ & $61(78 / 129)$ \\
\hline $41-50$ & $42(29 / 69)$ & $16(18 / 110)$ & $30(21 / 69)$ & $36(40 / 110)$ & $28(19 / 69)$ & $47(52 / 110)$ \\
\hline $51-60$ & $39(49 / 126)$ & $31(18 / 59)$ & $28(35 / 126)$ & $24(14 / 59)$ & $33(42 / 126)$ & $46(27 / 59)$ \\
\hline $61-70$ & $51(83 / 162)$ & $30(9 / 30)$ & $26(42 / 162)$ & $33(10 / 30)$ & $23(37 / 162)$ & $37(11 / 30)$ \\
\hline $71-80$ & $51(38 / 74)$ & $40(4 / 10)$ & $23(17 / 74)$ & $40(4 / 10)$ & $26(19 / 74)$ & $20(2 / 10)$ \\
\hline \multicolumn{7}{|l|}{ Chi-square': $104.46^{*}$} \\
\hline \multicolumn{7}{|l|}{ Population density } \\
\hline Oslo and surrounding area & $37(38 / 102)$ & $20(22 / 110)$ & $25(25 / 102)$ & $26(29 / 110)$ & $38(39 / 102)$ & $54(59 / 110)$ \\
\hline Bergen, Stavanger, Trondheim & $39(32 / 82)$ & $14(13 / 92)$ & $21(17 / 82)$ & $26(24 / 92)$ & $40(33 / 82)$ & $60(55 / 92)$ \\
\hline City with $20,000-100,000$ inhabitants & $46(62 / 136)$ & $17(20 / 116)$ & $33(43 / 62)$ & $23(27 / 116)$ & $23(31 / 136)$ & $60(69 / 116)$ \\
\hline City or town with $<20,000$ inhabitants & $41(65 / 160)$ & $23(28 / 122)$ & $31(50 / 65)$ & $29(35 / 122)$ & $28(45 / 160)$ & $48(56 / 122)$ \\
\hline Sparsely populated area & $45(41 / 91)$ & $22(15 / 68)$ & $29(26 / 91)$ & $29(20 / 68)$ & $26(24 / 91)$ & $49(33 / 68)$ \\
\hline \multicolumn{7}{|l|}{ Chi-square men: 12.70} \\
\hline \multicolumn{7}{|l|}{ Chi-square women: 5.87} \\
\hline \multicolumn{7}{|l|}{ Parental status } \\
\hline Has children & $47(202 / 426)$ & $23(70 / 309)$ & $25(105 / 426)$ & $29(89 / 309)$ & $28(119 / 426)$ & $49(150 / 309)$ \\
\hline Does not have children & $25(36 / 145)$ & $15(30 / 204)$ & $38(55 / 145)$ & $23(47 / 204)$ & $37(54 / 145)$ & $62(127 / 204)$ \\
\hline \multicolumn{7}{|l|}{ Chi-square men $23.15^{*}$} \\
\hline \multicolumn{7}{|l|}{ Chi-square women: $9.80^{*}$} \\
\hline \multicolumn{7}{|l|}{ Education } \\
\hline $\begin{array}{l}\text { Primary/elementary school and } \\
\text { lower secondary school }^{\mathrm{d}}\end{array}$ & $33(21 / 63)$ & $24(11 / 45)$ & $43(27 / 63)$ & $29(13 / 45)$ & $24(15 / 63)$ & $47(21 / 45)$ \\
\hline Upper secondary school & $43(68 / 158)$ & $21(38 / 178)$ & $32(50 / 158)$ & $28(49 / 178)$ & $25(40 / 158)$ & $51(91 / 178)$ \\
\hline University/College degree & $44(104 / 238)$ & $18(36 / 202)$ & $23(55 / 238)$ & $26(53 / 202)$ & $33(79 / 238)$ & $56(113 / 202)$ \\
\hline University/College higher degree & $41(44 / 108)$ & $17(14 / 82)$ & $26(28 / 108)$ & $22(18 / 82)$ & $33(36 / 108)$ & $61(50 / 82)$ \\
\hline \multicolumn{7}{|l|}{ Chi-square men: 12.38} \\
\hline \multicolumn{7}{|l|}{ Chi-square women: 3.81} \\
\hline \multicolumn{7}{|l|}{ Political affiliation } \\
\hline Social democratic and socialist parties & $27(52 / 195)$ & $9(18 / 202)$ & $28(54 / 195)$ & $22(44 / 202)$ & $46(89 / 195)$ & $69(140 / 202)$ \\
\hline Center and right wing parties & $50(163 / 328)$ & $30(68 / 229)$ & $28(93 / 328)$ & $28(64 / 229)$ & $22(72 / 328)$ & $42(97 / 229)$ \\
\hline \multicolumn{7}{|l|}{ Chi-square men: $38.09^{*}$} \\
\hline \multicolumn{7}{|l|}{ Chi-square women: $39.04 *$} \\
\hline \multicolumn{7}{|l|}{ Religious faith } \\
\hline No or low faith & $29(69 / 242)$ & $9(18 / 200)$ & $27(66 / 242)$ & $20(39 / 200)$ & $44(107 / 242)$ & $72(143 / 200)$ \\
\hline Some faith & $45(96 / 214)$ & $19(41 / 213)$ & $31(67 / 214)$ & $33(70 / 213)$ & $24(51 / 214)$ & $48(102 / 213)$ \\
\hline High faith & $64(66 / 104)$ & $41(39 / 95)$ & $23(24 / 104)$ & $26(25 / 95)$ & $14(14 / 104)$ & $33(31 / 95)$ \\
\hline \multicolumn{7}{|l|}{ Chi-square men: $52.15^{*}$} \\
\hline Chi-square women: $62.00^{*}$ & & & & & & \\
\hline
\end{tabular}

$* p<0.01$

${ }^{a}$ Participants reported that they were negative towards at least five out of six questions concerning attitudes towards gay and lesbian couples being granted the same legal rights to become parents as heterosexual couples

${ }^{\mathrm{b}}$ Participants reported that they were positive towards at least five out of six questions concerning attitudes towards gay and lesbian couples being granted the same legal rights to become parents as heterosexual couples

${ }^{\mathrm{c}}$ Chi-square was not calculated separately for men and women owing to the small sample size in the oldest age group

${ }^{d}$ This response alternative was originally two separate questions (7 years of school and 9 or 10 years of school) 


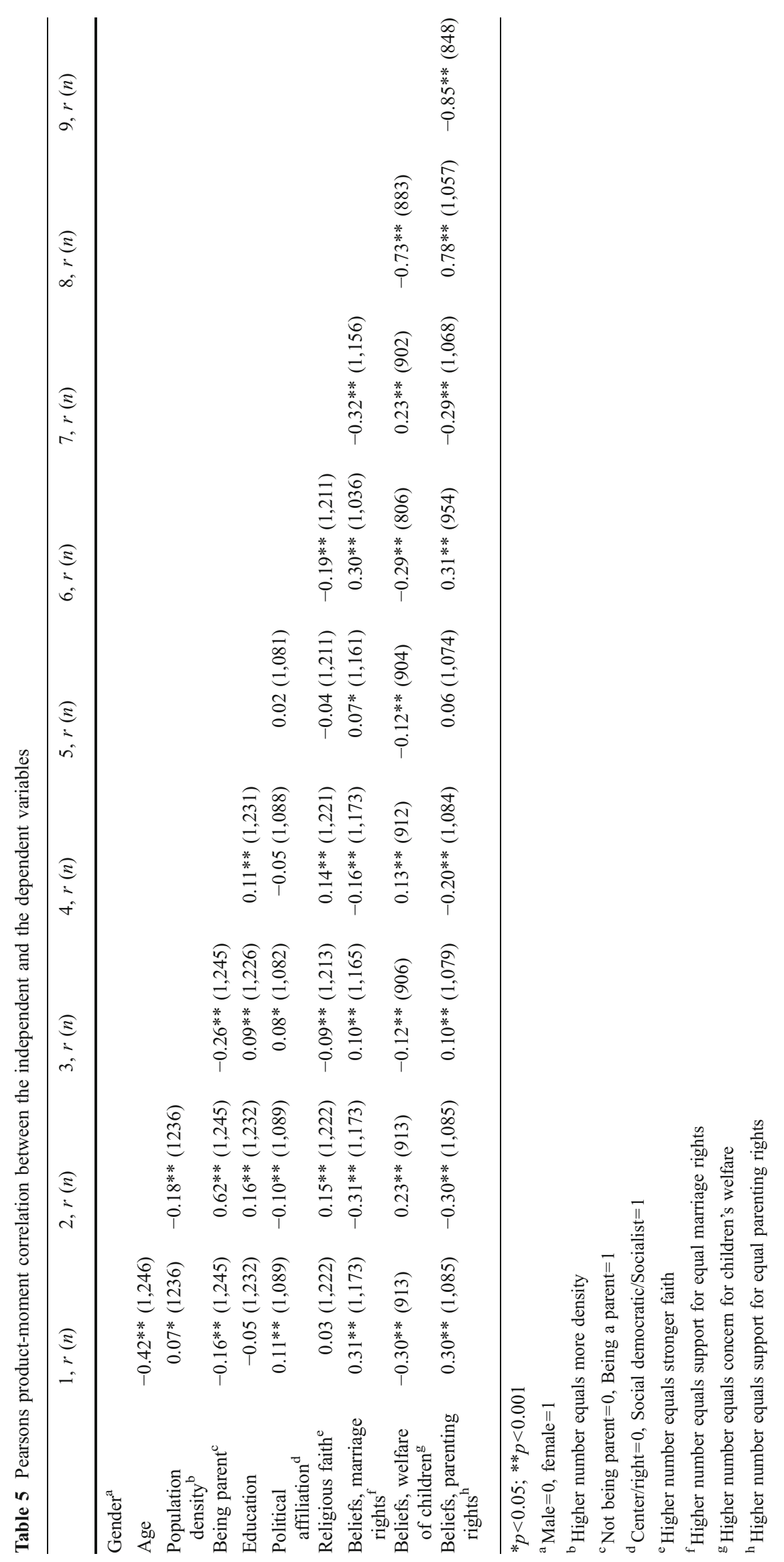


men, 30\%) should be allowed in Norway. Again, some respondents $(25-29 \%)$ reported that they neither agreed nor disagreed, or that they were uncertain in relation to these questions. Overall, men were more negative towards surrogacy arrangements abroad (54\%) and the legalization of egg donation (23\%) and surrogacy (44\%) in Norway compared with women $(31 \%, 13 \%$ and $27 \%$, respectively).

Beliefs About the Welfare of Children with Lesbian and Gay Parents

A minority expressed concern about the welfare of children with lesbian and gay parents. Overall, more men than women believed that growing up with lesbian and gay parents affects the children's welfare negatively (see Table 3). For example, more men than women reported that they do not believe that lesbian and gay parents could meet children's needs and interests fully and that children with lesbian or gay parents are more exposed to being bullied. Somewhat more participants agreed that children who grow up with lesbian parents as opposed to gay parents are just as well off as other children. Overall, a large proportion of the participants stated that they neither agreed nor disagreed, or they were uncertain about the welfare of children with gay and lesbian parents.

\section{Demographics and Beliefs About Equal Parenting Rights}

Table 4 shows the percentage of participants who expressed negative, positive and neither positive nor negative attitudes towards granting gay and lesbian couples the same legal rights to become parents as heterosexual couples, stratified by selected background variables. Male participants, older participants, those who were parents, those who reported that they would vote for centre and right-wing parties, and those who reported that they have a high religious faith were most negative towards granting gay and lesbian couples equal parenting rights. Population density and level of education were not statistically significant with regard to attitudes towards granting gay and lesbian couples the same legal rights as heterosexual couples to become parents.

Similar analyses were performed to identify the background variables of the participants who had negative attitudes towards equal marriage rights (those who responded negatively to at least two out of the three statements on beliefs about equal marriage rights scale) and also for participants who had concerns about the welfare of children with gay and lesbian parents (those who expressed concerns on at least five out of eight statements on beliefs about the welfare of children with lesbian and gay parents scale). Male participants $\left(\chi^{2}=87.49, p=0.00\right)$, older partic- ipants $\left(\chi^{2}=134.49, p=0.00\right)$, participants from less populated areas $\left(\chi^{2}=19.37, p=0.01\right)$, those who were parents $\left(\chi^{2}=29.93, p=0.00\right)$, those who reported that they would vote for centre and right-wing parties $\left(\chi^{2}=86.08, p=0.00\right)$ and those who reported that they have a high religious faith $\left(\chi^{2}=109.96, p=0.00\right)$ were most negative towards equal marriage rights for lesbian, gay and heterosexual couples. Male participants $\left(\chi^{2}=0.73, p=0.00\right)$, older participants $\left(\chi^{2}=0.26, p=0.00\right)$, those who were parents $\left(\chi^{2}=11.27, p=\right.$ 0.00 ), those who reported that they would vote for centre and right-wing parties $\left(\chi^{2}=48.59, p=0.00\right)$ and those who reported that they have a high religious faith $\left(\chi^{2}=58.92, p=\right.$ 0.00 ) also expressed the most concerns about the welfare of children with gay and lesbian parents. Level of education $\left(\chi^{2}=11.76, p=0.07\right)$ was not statistically significant with regard to attitudes towards equal marriage rights, whilst level of education $\left(\chi^{2}=12.51, p=0.05\right)$ and population density $\left(\chi^{2}=14.17, p=0.08\right)$ were not statistically significant with regard to concerns about the welfare of children with gay and lesbian parents.

Table 5 shows the correlations between all variables (utilizing sum scores for the three belief scales). Because beliefs about equal marriage rights for lesbian, gay and heterosexual couples (scale) were highly correlated with beliefs about the welfare of children with lesbian and gay parents (scale, $r=-0.73$ ), the scale concerning marriage rights was not included in the regression analysis as an independent variable because it would induce multicollinearity.

\section{Conceptual Model}

A hierarchical multiple regression analysis was performed to examine predictors of "Beliefs about equal parenting rights for lesbian, gay and heterosexual couples" (sum score of full scale). The background variables gender, age, population density, being a parent, education, political affiliation and religious faith were entered on the first step. When the eight-item scale, "Beliefs about the welfare of children with lesbian and gay parents", was taken into consideration whilst controlling for background variables, the model was statistically significant $[F(8,797)=296.28, p=0.00]$ (see Table 6). "Beliefs about the welfare of children with lesbian and gay parents" explained an additional $49 \%$ of the variance in beliefs that lesbian and gay couples should be granted the same legal rights to become parents as heterosexual couples. In this model, gender, age, population density and education did not explain any of the variance, whereas being parents, political affiliation and religious faith also made a substantial contribution to explaining beliefs about equal parenting rights for lesbian, gay and heterosexual couples. 
Table 6 Predictors of the belief that gay and lesbian couples should be granted the same legal rights to become parents as heterosexual couples

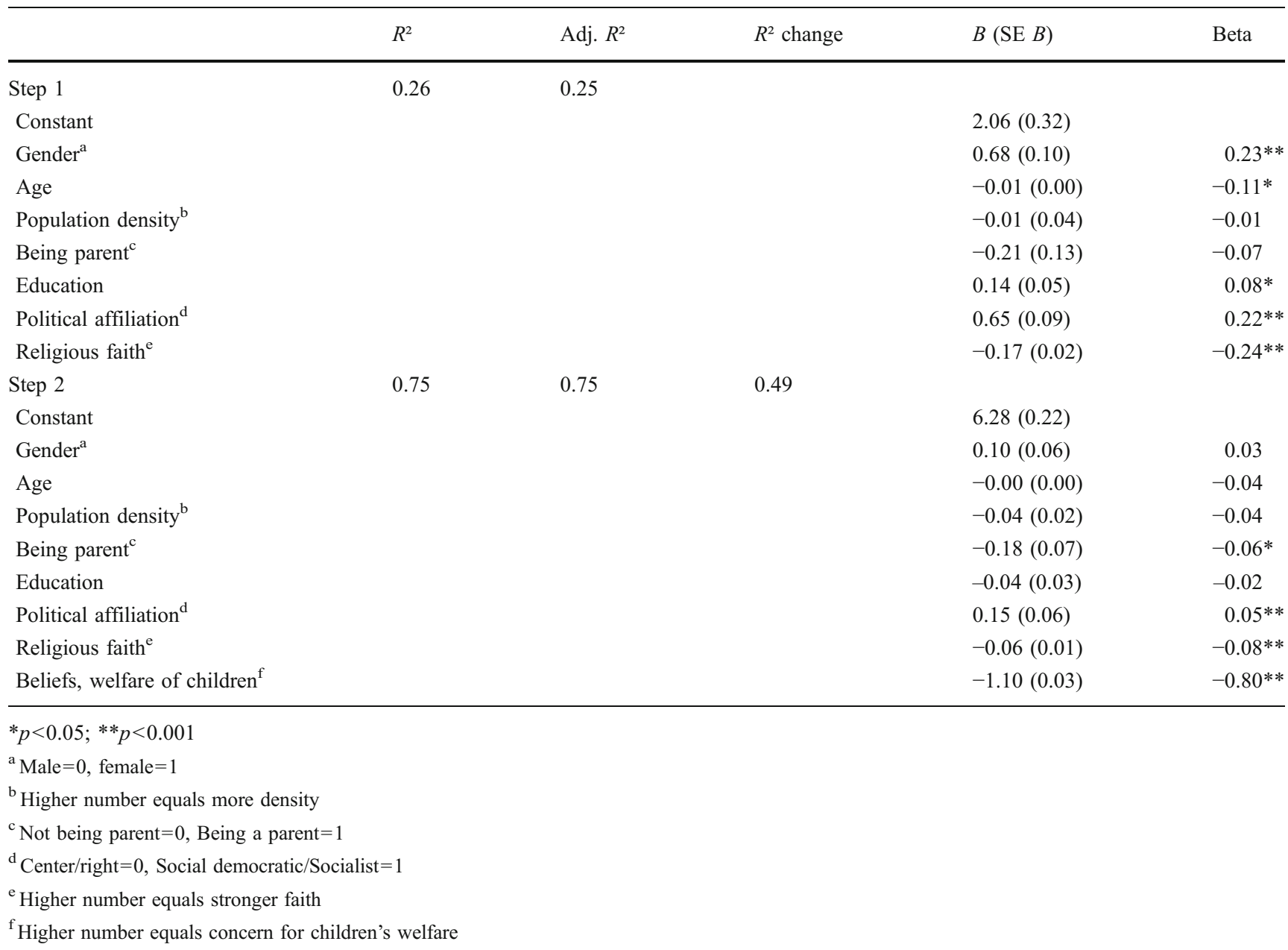

\section{Discussion}

The results may be summarized into three main findings. First, there seems to be extensive support for equal marriage rights for same-sex couples in the Norwegian population. Our data indicate that two thirds of the Norwegian population support equal civil marriage rights for lesbian, gay and heterosexual couples, and the majority also supports equal rights to church weddings. Taking the difficulty of comparing various results due to disparate methods of assessment into consideration, the support for equal marriage rights in Norway appears, in addition to be quite high, also to be quite stable. Already in 1998, nearly half the Norwegian population supported equal right to church weddings for lesbian, gay and heterosexual couples (MMI 1998). Second, the current data show that the majority of the Norwegian population is against, unwilling to take a stand or uncertain concerning equal parenting rights for lesbian, gay and heterosexual couples. The increase in support for adoption rights is, on the other hand, seemingly quite distinct. Close to half of our sample believed that the right to apply for adoption should be independent of sexual orientation as compared to 1998 when only $25 \%$ of the Norwegian population supported such rights (EOS Gallup Europe 2003; MMI 1998). Similar trends are seen in other Scandinavian countries and in the USA where the majority of the population at present seem to support adoption rights for lesbian and gay couples (EOS Gallup Europe 2003; European Commission 2006; People Press Organization 2009). Third, the current findings show that half the participants are unwilling to take a stand, are concerned or uncertain regarding the welfare of children who grow up with lesbian and gay parents. In 1998, this was the case for somewhat more than half the sample, but a larger proportion then reported that they were explicitly concerned as opposed to not taking a stand or being uncertain (MMI 1998). Population concerns in relation to lesbian and gay parenthood are also reported in earlier studies from other countries (Crawford and Solliday 1996; King 2001; McLeod et al. 1999; Morse et al. 2008).

More men than women reported that they hold negative beliefs about equal marriage and parenting rights for gay, lesbian and heterosexual couples. More men than women 
were also concerned about the welfare children with lesbian and gay parents. This is consistent with attitude studies showing that men's attitudes towards lesbian women and gay men generally tend to be more negative (Herek 2002). According to Steffens and Wagner (2004), unfavorable attitudes towards homosexuals are often rooted in people's gender belief systems, or "the broader belief system about women, men, and their appropriate roles" (p. 138). These belief systems (or systems that tell us what it is to be a man or a woman, respectively) have in general been more rigid and restricted for men and masculinity than for women and femininity (Anderssen 2002; Kite and Whitley 1996). Our data further show that being older, being a parent, having a high religious faith and voting for centre or right-wing parties also predict negative beliefs about equal marriage and parenting rights for lesbian, gay and heterosexual couples as well as concern for the welfare of children with lesbian and gay parents. Our findings are in general consistent with those existing in literature from other countries. The fact that beliefs about same-sex marriage rights, lesbian and gay parenthood and beliefs about the welfare of children with lesbian and gay parents at large are predicted by the same demographic variables, including religion and political affiliation, is supported by earlier findings (e.g. Brumbaugh et al. 2008; EOS Gallup Europe 2003; Pearl and Galupo 2007; Morse et al., 2008). Research on population attitudes towards lesbian and gay parenting further suggests that negative attitudes are associated with antigay attitudes and sexual prejudice (Crawford and Solliday 1996; Morse et al. 2008). One explanation for this could be that people with antigay attitudes and sexual prejudice more easily feel threatened by change and flexing of societal boundaries, with beliefs more often based on stereotypes and traditional family scripts (Morse et al. 2008).

\section{Policy Processes and Beliefs About Equal Marriage and Parenting Rights}

Two thirds of the population supports equal civil marriage rights, and there is majority support for equal right to church weddings. Whilst the proportion of the population who supports equal adoption rights is growing, the majority of the Norwegian population is against or uncertain concerning equal parenting rights for lesbian, gay and heterosexual couples. We want to point to some interrelated policy processes to understand this.

First, according to Kurtz (2004), extensive support for gay marriage-like rights must be understood in light of the changing role of marriage in Scandinavian countries. High rates of cohabitation and family policies that reflect a flexible and pragmatic adaptation to these changing cohabitation patterns (including systems for financial support; Noack 2001) make it plausible that Scandinavian populations are more likely than others to support same-sex marriage rights and be innovators in giving marriage-like rights to gays and lesbians. Behind such developments are long-term trends such as a decline in religious beliefs and practices (secularism), a strong welfare state, early advances in contraception and abortion, high female employment and increased status of women through economic independence (Kurtz 2004).

Second, the high support for equal marriage rights and the growing support for adoption rights may be understood as a result of incremental legal changes for both these issues. It is reasonable to think that a Partnership Act since 1993, which secured most marriage-like rights with the exception of equal rights to become parents, has had a distinct effect on the present positive population attitudes towards equal marriage rights in the Norwegian population. As a relevant comparison, prior to the Partnership Act in 1993, only a few opinion polls indicated that the majority of the Norwegian population was in favour of a Partnership Act for same-sex couples (Halvorsen 1998). Another example of attitude change in a broader part of the Norwegian population is the fact that whilst the Christian People's Party opposed the Partnership Act in 1993, they expressed support for it in the debate fronting the new gender-neutral Marriage Act. Growing support for adoption rights may also partly be explained by incremental legal changes regarding gay adoption and fostering. The Law on Adoption from 2002 permitted adoption of stepchildren in lesbian and gay partnerships. In the period from 1993, when the Partnership Law was made effective, and until 2004, limited but still increased opportunities for lesbian and gay partners to become foster parents were introduced (Ministry of Children and Equality 2004). Interestingly, and in spite of the new gender-neutral Marriage Law, current foster care regulations uphold the principle that foster homes, as the main rule, should be heterosexual couples. Grønningsæter and Nuland (2008) points to this fact, claiming that such wording can be considered discriminatory.

In contrast to a gradual introduction of adoption and fostering rights for lesbian and gay couples, there has not been the same incremental growth in support for assisted fertilization for lesbian couples. Until the gender-neutral Marriage Law was enacted in 2009, lesbian couples could not receive state-sponsored assisted fertilization in Norway. Therefore, this may also partly explain the lower support for such services at present. A related theme can be illustrated by Dalton and Bielby (2000) who stated that family institutions are linked powerfully to basic and fundamental family scripts. These scripts appear to change much more slowly than the actual development of different family forms. It is therefore to be expected that support for parenting rights may correspond to their level 
of deviation from fundamental family scripts (Morse et al. 2008). More support for adoption rights for lesbian and gay couples than support for state-sponsored assisted fertilization for lesbian couples may indicate that this is the case also in the Norwegian population. In general, we want to point out that whilst formal recognition of practices or behaviours in laws and regulations has effects on population attitudes, these processes are not unidirectional. Introduction of legal changes also needs a certain level of population support, as well as majority support in Parliament.

Third, higher support of marriage rights than parenting rights for lesbian and gay couples may relate to the fact that marriage and childbearing have become less directly connected over time, in Scandinavian countries especially (Halvorsen 1998; Kiernan 2001). In 1997, more than 40\% of children born in Nordic countries were born outside marriage (Kiernan 2001). In 2009, this was the case for $56 \%$ of Norwegian children (Statistics Norway 2010a, b). Consequently, the nexus between marriage and reproduction has been broken (Badgett 2004). Norway is a good example of a country where relationships with children and relationships between two adults increasingly have been seen as two different social phenomena. The relationship between two adults have for a long time been considered a private matter for most people in Norway. However, parenthood, implying a third party (the child) now also with own specific rights, has mainly been considered differently, where society should both have a special responsibility and a say (Halvorsen 1998). Such trends are most likely reflected in our findings where large parts of the Norwegian population seemingly feel much more at ease with marriage rights as compared with parenting rights for lesbian and gay couples.

Fourth, and following the reflections above, opposition to lesbian and gay parenting has until recently been visible and clearly reflected in, for example, both Council of Europe's recommendations to member states (Swedish Official Report 2001) and in Norwegian law (Danielsen 2005). Therefore, as Graham says, "both public opinion and the law until recently, also in Scandinavian countries, have regarded heterosexual married couples as the privileged locus for reproduction of persons, and more precisely citizens" (Graham 2004, p. 27). In addition to more limited incremental changes concerning parenting rights for lesbian and gay couples compared with other marriage-like rights, policy regulations and provisions in Norwegian law have at the same time discouraged lesbian and gay parenthood (Danielsen 2005). Our findings therefore support Morse et al. (2008) who claim that an apparent positive attitudinal shift towards lesbian and gays in general, to a lesser extent, includes lesbian and gay parenting and the question of lesbian and gay parenthood.
Finally, we want to comment on the findings concerning Norwegian beliefs about egg donation and surrogacy. This practice is still illegal in Norway, but at present quite widely discussed, also because using egg donation and surrogacy abroad have gradually become more common among both single parents and heterosexual, gay and lesbian couples (European Society of Human Reproduction and Embryology 2009). These technologies constitute reproduction strategies most deviant to traditional family scripts (Dalton and Bielby 2000; Morse et. al. 2008), something that may partly explain why there were no proposals in Proposition nr. 33 (2007-2008) concerning provisions for such services in the new Norwegian genderneutral Marriage Act. Still, in our sample, there is a clear majority support for legalizing egg donation and more people who support surrogacy services in regulated forms in Norway compared with the support for gay men using surrogacy services abroad. These findings may partly be explained by an increased emphasis on rights perspectives in the public. On one hand, it may indicate more openness and increased emphasis on an equal rights perspective in relation to who should have the right to become parents. In addition, these findings may also be understood in light of increased emphasis on children as own right holders. Children's right to knowledge about their own biological origin and rights such as protection from being bought and sold have found their way into the United Nation Convention on the Rights of the Child as well as into Norwegian law. Such rights are, however, poorly protected in many unregulated foreign-assisted fertility markets. Both these phenomena have most likely influenced the present quite extensive support for legalizing egg donation in Norway and may partly explain why more people seemingly support surrogacy in regulated forms in Norway compared with gay men using such services abroad.

Concern for the Welfare of Children with Lesbian and Gay Parents-What is it About?

The main predictor of negative beliefs about equal parenting rights for lesbian, gay and heterosexual couples are concerns about the welfare of children with lesbian and gay parents. We will make some comments on this, based on our findings, and the debate ahead of the Norwegian gender-neutral Marriage Act.

First, participants in this study seemed to perceive outside factors that are beyond the control of the parents (e.g. bullying or negative social reactions) to be a greater threat to children's welfare than growing up with lesbian and gay parents in itself. The Norwegian population may therefore have become less affected by traditional developmental theories and their predictions of negative outcomes for children who are raised in nontraditional 
families (Lambert 2005) or by more ideological viewpoints such as lesbian and gay parenthood not being normal or natural (Clarke 2001; Folgerø 2008). Instead, their main concerns seemingly focus on how children and their lesbian and gay parents are treated, accepted and included in the wider society. For example, whilst $60 \%$ of the sample said that sexual orientation does not matter for good parenting, only $40 \%$ of the sample thought that the society is ready for children growing up with lesbian and gay parents. Whilst research has not documented serious negative developmental effects for children who are raised by lesbian and gay parents (e.g. Crowl et al. 2008; Biblarz and Stacey 2010), increased likelihood for negative reactions and stigmatization have been reported by some (e.g. Fairtlough 2008; Robitaille and Saint-Jacques 2009; Stefansen et al. 2009). Questions and concern in relation to possible negative social reactions and bullying of children who grow up with lesbian and gay parents are therefore relevant and must not be ignored. It is also, on the other hand, known that increased risks of stigmatization and bullying are frequently used as arguments for undermining or opposing lesbian parenthood in general (Clarke et al. 2004). This should also be considered when trying to explain the present results.

Second, our findings further suggest that there is higher uncertainty and unwillingness to take a stand than direct concern regarding the welfare of children with lesbian and gay parents. Whilst more than one third was either unwilling to express a view or reported that they were uncertain about how to perceive the welfare of children with lesbian and gay parents, overall, $<20 \%$ expressed concern. This is very different from 1998 when $41-48 \%$ of the Norwegian population expressed concern about this and $<15 \%$ found this question difficult to answer (MMI 1998). Persons with higher education are overrepresented in the present sample. However, we believe that the change in proportions from 1998 until 2008 still indicates a movement in the Norwegian population in the direction of more openness regarding issues related to lesbian and gay parenting and children's welfare. This would be similar to what Grønningsæter and Nuland (2008) refer to has taken place in relation to lesbian and gay love, partnership and sexuality in general. Increased acceptance of nonheterosexual expressions are most often explained by incremental changes combined with increased visibility in a range of societal arenas (Anderssen and Slåtten 2008). Such developments are now the case also for lesbian and gay parenting. Why many seemingly have replaced direct concern with playing a more waiting game in relation to attitudes towards lesbian and gay parenthood and the welfare of children with lesbian and gay parents may partly be understood in light of these trends. Our findings therefore also shade the statement of Morse et al. (2008) that a general positive attitudinal shift towards homosexuals in general does not yet include lesbian and gay parenting and the question of lesbian and gay parenthood. Similarly, Herek (2006) says that in the current debate in the USA on these and related questions, people appear to have replaced definite opinions with holding parallel and conflicting values, on one hand adhering to traditional beliefs but on the other hand also valuing fairness, rights and nondiscrimination.

Third, the fact that concerns regarding the welfare of children with lesbian and gay parents turn out to be the most significant predictor of negative attitudes towards granting equal parenting rights to lesbian, gay and heterosexual couples also invites some further reflections, beyond the discussions above. Folgerø (2008) argues that lesbian and gay parenthood challenges cornerstones of Western civilization such as normative discourses on genetic parenthood (the right to know one's genetic origin), children as a result of romantic love, the need for and the right to have two parents, and the necessity for complementary gender roles in parents to secure a healthy psychosocial development. Population concerns in relation to lesbian and gay parenting and the welfare of children with gay and lesbian parents are therefore to be expected (Herek 2006). Concern and uncertainty were prevalent both in the Norwegian public debate preceding the new genderneutral Marriage Act and in our findings. Both supporters and opponents of the Norwegian gender-neutral Marriage Act (Proposition nr. 33 2007-2008) seemingly placed high value on children's welfare, needs and interests, and the importance of children as own right holders in relation to lesbian and gay parenthood. On one hand, this may reflect that children, as bearers of their own rights and with their own interests to be heeded, have become a well-established construct in Norwegian society. On the other hand, it also shows that the definition of these needs and interests and the meaning of children's own rights in relation to lesbian and gay parenthood are contested.

Supporters of equal rights for homosexuals and heterosexuals have traditionally emphasized a rights perspective, whilst opponents more often have invoked arguments in relation to religion or tradition to support their position (Herek 2006; Price et al. 2005). In relation to equal parenting rights for lesbian, gay and heterosexual couples in Norway, opponents of such provisions in law have also adopted a children's rights perspective or the use of "rights" language. Even so, without necessarily endorsing egalitarian values in general (Ellis et al. 2002), opponents seem to be trying to define children's rights, needs and interests within the framework of religious and traditional arguments. With respect to lesbian and gay parenthood, children's rights then imply the right to have a traditional, normal and "natural" family with two parents of opposite sexes, etc. Whilst there 
has been relatively high and stable support for same-sex marriage rights in Norway over time, there has been more indecision and uncertainty in relation to equal parenting rights for lesbian, gay and heterosexual couples. This may have left the field more open to influence or discussions about what children's needs and interests are in relation to gay parenthood and what is meant by children as bearers of their own rights in respect of these questions. It may therefore have been a strategic choice for opponents to focus on a children's rights perspective when arguing against provisions for equal parenting rights for lesbian and gay parents in the new gender-neutral Marriage Act. Halvorsen (1998) claims that one way of neutralizing controversial political views or arguments that are taboo may be to use euphemisms. In relation to questions about equal parenting rights for lesbian, gay and heterosexual couples, a children's rights perspective fronted by the opponents of the new gender-neutral Marriage Act may therefore also be understood as a euphemism for more controversial arguments based on religion or tradition, or even taboo arguments such as lesbian and gay parents being of less value or of a different quality.

\section{Why Norway, Why Now?}

Norway was first among the Nordic countries to adopt a progressive gender-neutral Marriage Act. This is interesting, taking the fact that there historically have been less liberal attitudes towards family policy and alternative family forms in Norway as compared with, for example, Sweden (European Commission 2006). Less liberal attitudes may be understood in light of factors such as less urban living and a somewhat more general conservative religious and political landscape in Norway. In Norway, a Christian People's Party, with profession of faith for their representatives, has been part of a centre or centre/right coalition government on four different occasions between 1985 and 2005. Norway has also, since the 1990s, and differently from for example Sweden, had a quite large opposition party, the Progress Party, located at the far right in the political landscape. Between $15 \%$ and $23 \%$ of the Norwegian population has in the last 15 years given their votes to this party. It is reasonable to think that such a landscape reflects slightly more conservative attitudes, which again are known to affect the level of support for equal marriage and parenting rights for lesbian, gay and heterosexual couples (e.g. Brumbaugh et al. 2008; Pearl and Galupo 2007; EOS Gallup Europe 2003).

The fact that a new gender-neutral Marriage Act was passed already in 2008 in Norway may be explained by several circumstances, also partly coinciding in time. In 2003, the United Nation Convention on the Rights of the Child was incorporated in the Norwegian Human Rights Law (1999). This law takes precedence over national law in case of contradictory provisions (Sandberg 2004) and brought up to date children's rights on a number of different arenas in the Norwegian society. Two years later, in 2005, Norway had a shift to a social democratic/socialist/ green coalition government with a majority in Parliament. The political shift was contrary to the present political trend in many European countries, and in Norway, this was the first majority government since the mid 1980s, a government coalition which, for the first time in history, also included the Socialist Left-Wing Party. Such circumstances have most likely encouraged both the promotion and the enactment of a new a gender- neutral Marriage Act.

\section{Limitations}

Whilst a Web sample cannot be fully representative, we believe that the study presents attitudes reflected in the Norwegian population. A Web-based solution was particularly suitable for our purpose because we were assessing beliefs about sensitive themes and we specifically wanted to avoid social desirability when answering.

The present findings are drawn from data in a larger survey that assessed beliefs or attitudes towards a number of topics related to lesbian, gay, bisexual and transsexual persons. Because of the sparse research literature on these topics, we had to develop the questionnaire ourselves by using measures based on polls and items in survey research on attitudes towards lesbian and gay people, framed according to contemporary Norwegian laws and context. Two pilot studies were conducted.

We realize that construct validity and test-retest reliability have yet to be established. The survey topics, the available response categories and the sequence of questions all may have affected the direction of participants' responses to the items on attitudes towards same-sex marriage, lesbian and gay parenting and the welfare of children with lesbian and gay parents. Furthermore, the questionnaire items provided both the response categories "Neither agree nor disagree" and "Uncertain". This may have influenced the number of people who chose not to express an opinion on the issues in question. Finally, whilst the sample at large reflected the demographic profile in Norway, participants with a university/college degree were overrepresented in our study. As higher education is known to positively affect beliefs about marriage and parenting rights for lesbian and gay couples (Brumbaugh et al. 2008; Pearl and Galupo 2007), this has to be taken into account when reading the findings.

The items used in the present analyses were placed towards the end of the questionnaire. When responding to these items, the sample had already expressed opinions on a number of questions relating to gay, lesbian, bisexual and transgender issues. This may have led either to a reinforcing of beliefs or an increased level of reflection. 


\section{Conclusions}

This nationwide study investigated the Norwegian public's beliefs about equal marriage and parenting rights for lesbian, gay and heterosexual couples and the welfare of children with lesbian and gay parents. Our findings show extensive support for equal civil marriage rights and majority support for equal rights to church weddings. Less than half the sample support equal parenting rights, but our findings indicate growing support for equal adoption rights for lesbian, gay and heterosexual couples. Being male, parent, and of older age, having a high religious faith and voting for centre/right-wing parties all predict negative beliefs about both equal marriage and parenting rights for lesbian, gay and heterosexual couples as well as concern for the welfare of children with lesbian and gay parents. When considering the predictors of attitudes towards equal parenting rights especially and controlling for a range of demographic variables, religiosity and political affiliation, our findings show that concern for the welfare of children with lesbian and gay parents is the main predictor of a negative attitude towards equal parenting rights for lesbian, gay and heterosexual couples.

An area of interest for future research may be a children's rights perspective in relation to lesbian and gay parenthood. It would be of particular interest to investigate more closely what children's own rights may mean in relation to lesbian and gay parenthood and how different stakeholders understand and shape the idea of children as own right holders in relation to constructs such as lesbian and gay parenting and the welfare of their children. Such knowledge may also inform suitable future intervention strategies to secure non-discrimination and inclusion for both lesbian and gay parents and their children.

Open Access This article is distributed under the terms of the Creative Commons Attribution Noncommercial License which permits any noncommercial use, distribution, and reproduction in any medium, provided the original author(s) and source are credited.

\section{References}

Anderssen, N. (2002). Does contact with lesbians and gays lead to friendlier attitudes? A two year longitudinal study. Journal of Community and Applied Social Science, 12, 124-136.

Anderssen, N., \& Hellesund, T. (2009). Heteronormative consensus in the Norwegian same-sex adoption debate? Journal of Homosexuality, $56,102-120$.

Anderssen, N., \& Slåtten, H. (2008). Holdninger til lesbiske, homofile menn, bifile kvinner og menn og transpersoner (LHBT-personer). En landsomfattende representativ spørreundersøkelse [Attitudes towards lesbian, gay, bisexual women and men, and transpersons. A national representative survey]. Bergen: Avdeling for samfunnspsykologi, Universitetet i Bergen.
Biblarz, T. J., \& Stacey, J. (2010). How does the gender of parents matter. Journal of Marriage and the Family, 72, 3-22.

Badgett, M. V. L. (2004). Will providing marriage rights to same-sex couples undermine heterosexual marriage? Sexuality Research \& Social Policy, 1(3), 1-10.

Brumbaugh, S. M., Sanchez, L. A., Nock, S. L., \& Wright, J. D. (2008). Attitudes toward gay marriage in states undergoing marriage law transformation. Journal of Marriage and the Family, 70, 345-359.

Clarke, V. (2001). What about the children? Arguments against lesbian and gay parenting. Womens Studies International Forum, 24(5), 555-570.

Clarke, V., Kitzinger, C., \& Potter, J. (2004). 'Kids are just cruel anyway': Lesbian and gay parents' talk about homophobic bullying. The British Journal of Social Psychology, 43, 531-550.

Crawford, I., \& Solliday, E. (1996). The attitudes of undergraduate college students toward gay parenting. Journal of Homosexuality, 30(4), 63-77.

Crowl, A. L., Ahn, S., \& Baker, J. (2008). A meta-analysis of developmental outcomes for children of same-sex and heterosexual parents. Journal of GLBT Family Studies, 4, 385-407.

Dagsavisen. (2005, April 21). Seks av ti sier ok til kjønnsnøytral ekteskapslov [Six out of ten says ok to a gender-neutral marriage law]. Dagsavisen. Retrieved from http://www.dagsavisen.no/ innenriks/article1552235.ece.

Dalton, S. E., \& Bielby, D. D. (2000). That's our kind of constellation. Lesbian mothers negotiate institutionalized understandings of gender within the family. Gender \& Society, 14(1), 36-61.

Danielsen, K. (2005). Diskriminering - en litteraturgjennomgang [Discrimination - a literature review]. Oslo: Norsk Institutt for Forskning om Oppvekst, velferd og aldring. 4/05.

Ellis, S. J., Kitzinger, C., \& Wilkinson, S. (2002). Attitudes towards lesbians and gay men and support for lesbian and gay human rights among psychology students. Journal of Homosexuality, 44 (1), 121-138.

EOS Gallup Europe. (2003). Homosexual marriage, child adoption by homosexual couples: is the public ready? Retrieved from www. eosgallupeurope.com.

Eskridge, W. N. (2001). The ideological structure of the same-sex marriage debate. In R. Wintemute \& M. Andenæs (Eds.), Legal recognition of same-sex partnership. Oxford: Hart Publishing.

European Commission. (2006). Public opinion in the European Union. First results. Standard Eurobarometer 66. Retrieved from http://ec.europa.eu/public_opinion/archives/eb/eb66/eb66_en. htm.

European Society of Human Reproduction and Embryology. (2009). Retrieved from http://www.eshre.eu/ESHRE/English/GuidelinesLegal/ART-fact-sheet/page.aspx/1061.

Fairtlough, A. (2008). Growing up with a lesbian or gay parent: young people's perspectives. Health \& Social Care in the Community, 16(5), 521-528.

Folgerø, T. (2008). Queer nuclear families? Reproducing and transgressing heteronormativity. Journal of Homosexuality, 54(1), 124-149.

Government Commission. (2006). Parliamentary Report on the Family and the Rights of Children to the French National Assembly. Retrieved from http://www.assemblee-national.fr/12/ dossiers/mission_famille_enfants.asp.

Graham, M. (2004). Gay marriage: Whither sex? Some thoughts from Europe. Sexuality Research \& Social Policy, 1(3), 24-31.

Grønningsæter, A. B., \& Nuland, B. R. (2008). Diskriminering av lesbiske, homofile og bifile og av hivpositive [Discrimination of lesbians, gays and bi-sexuals, and HIV positive persons]. Oslo: Fafo.

Halvorsen, R. (1998). The ambiguity of lesbian and gay marriages. Journal of Homosexuality, 35(3), 207-231. 
Hegna, K., Kristiansen, H. W., \& Moseng, B. U. (1999). Levekår og Livskvalitet Blant Lesbiske Kvinner og Homofile Menn [Living conditions and life quality among lesbian women and gay men]. Oslo: Norsk institutt for forskning om oppvekst, velferd og aldring.1/99.

Herek, G. M. (2002). Gender gaps in public opinion about lesbian and gay men. Public Opinion Quarterly, 66, 40-66.

Herek, G. M. (2006). Legal recognition of same-sex relationships in the United States-A social science perspective. The American Psychologist, 61(6), 607-621.

Hicks, G. R., \& Lee, T. T. (2006). Public attitudes toward gays and lesbians: Trends and predictors. Journal of Homosexuality, 51(2), $57-77$.

ILGA-Europe. (2009). Marriage and partnership rights for same-sex partners: country-by-country. Retrieved from http://www.ilgaeurope.org/europe/issues/lgbt_families/marriage_and_partnership_ rights_for_same_sex_partners_country_by_country.

Kiernan, K. (2001). The rise of cohabitation and childbearing outside marriage in Western Europe. International Journal of Law, Policy and Family, 15, 1-21.

King, B. R. (2001). Ranking of stigmatization towards lesbians and their children and the influence of perceptions of controllability of homosexuality. Journal of Homosexuality, 41(2), 77-97.

Kite, M. E., \& Whitley, B. E. (1996). Sex differences in attitudes towards homosexual persons, behaviors, and civil rights: A meta-analysis. Personality and Social Psychology Bulletin, 22, 336-353.

Klassekampen. (2005). Ja til homoekteskap [Yes to homosexual marriage]. Klassekampen. Retrieved from http://www.llh.no/./?module $=$ Articles; action=Article.publicShow;ID=2709 (September 3).

Kurtz, S. (2004). No explanation. Gay marriage has sent the Netherlands the way of Scandinavia. Retrieved from http://old. nationalreview.com/kurtz/kurtz200406030910.asp (June 3).

Lambert, S. (2005). Gay and lesbian families: What we know and where to go from here. The Family Journal: Counseling and Therapy for Couples and Families, 13(1), 43-51.

Landèn, M., \& Innala, S. (2002). The effect of a biological explanation on attitudes towards homosexual persons. A Swedish national sample study. Nordic Journal of Psychiatry, 56(3), 181-186.

MMI. (1998). En telefonundersøkelse om nordmenns holdninger til lesbiske og homofiles rettigheter og levekår [A telephone inquiry about Norwegian attitudes towards lesbian's and homosexual's rights and living conditions]. In Rapport utarbeidet for NOVA av Erik Dalen. Oslo: MMI (2-4 Mars 1998).

McLeod, A. C., Crawford, C., \& Zechmeister, J. (1999). Heterosexual undergraduates' attitudes toward gay fathers and their children. Journal of Psychology and Human Sexuality, 11, 43-62.

Ministry of Children, Equality and Social Inclusion (2009a). A marriage Act for all. Retrieved from http:/www.regjeringen.no/ $\mathrm{nb} / \mathrm{dep} / \mathrm{bld} /$ tema/homofile-og-lesbiske/felles-ekteskapslovikrafttredelse-og-.html?id=509376.

Ministry of Children, Equality and Social Inclusion (2009b). Gender neutral Marriage Law-Effective from 1 January 2009. Retrieved 12 June 2009 from http://www.regjeringen.no/nb/dep/bld/tema/ homofile-og-lesbiske/felles-eksteskapslov.

Ministry of Children and Equality (2004). Retningslinjer for fosterhjem [Guidelines for fosterhomes]. Retningslinjer av 15. Juli til lov om barneverntjenester av 17. juli 1992 nr. 100. Retrieved from http://www.regjeringen.no/nb/dep/bld/tema/barnevern/ retningslinjer-for-fosterhjem.html?id=415699.

Morse, C. N., McLaren, S., \& McLachlan, A. J. (2008). The attitudes of Australian heterosexuals toward same-sex parents. Journal of GLBT Family Studies, 3(4), 425-455.

Noack, T. (2001). Cohabitation in Norway: An accepted and gradually more regulated way of living. International Journal of Law Policy and Family, 15, 102-117.

Olson, L. R., Cadge, W., \& Harrison, J. T. (2006). Religion and public opinion about same-sex marriage. Social Science Quarterly, 87 (2), 340-360.

Pallant, J. (2007). SPSS. Survival manual. A step by step guide to data analysis using SPSS for Windows (3rd ed.). New York: Open University Press.

Pearl, M. L., \& Galupo, M. P. (2007). Development and validation of the attitudes toward same-sex marriage scale. Journal of Homosexuality, 53(3), 117-134.

Peel, E., \& Harding, R. (2008). Editorial introduction: Recognizing and celebrating same-sex relationships: Beyond the normative debate. Sexualities, 11, 659 .

People Press Organization. (2009). Independents take center stage in Obama era: Section 4: Religion and social values. The Pew Research Center for the People \& the Press. Retrieved from http://people-press.org/report/?pageid=1519 (May 21).

Pew Forum. (2009). Majority continues to support civil unions. The Pew Forum on religious \& public life. Retrieved from http:// pewforum.org/docs/?DocID=481 (October 9).

Pew Research Center. (2009). The gay marriage debate: Where it stands. Retrieved 22 July 2009 from http://pewresearch.org/pubs/ 1279/gay-marriage-debate-2009? src=prc-latest\&proj=peo....

Price, V., Nir, L., \& Cappella, J. N. (2005). Framing public discussion of gay civil unions. Public Opinion Quarterly, 69(2), 179-212.

Proposition nr. 33. (2007-2008). Law on changes in the Marriage Act, Children's Law, Law on Biotechnology etc. (gender-neutral Marriage Act for heterosexual and homosexual couples).

Robitaille, C., \& Saint-Jacques, M. C. (2009). Social stigma and the situation of young people in lesbian and gay stepfamilies. Journal of Homosexuality, 56(4), 421-442.

Sandberg, K. (2004). Inkorporeringen av FN's barnekonvensjon i norsk rett [Incorporation of the United Nation Convention on the Rights of the Child in Norwegian legislation]. Kritisk Juss, 30, 316-329.

Statistics Norway (2010a). The information society. Statistics Norway-Statistisk sentralbyrå. Retrieved 01 September 2010 from http://www.ssb.no/english/subjects/10/03/ikt en/.

Statistics Norway (2010b) Høy fruktbarhet [High fertility]. Retrieved 11 October 2010 from http://www.ssb.no/fodte/.

Stefansen, K., Hegna, K., Valset, J., von Soest, T., \& Mossige, S. (2009). Vold mot "homofil" ungdom. Forekomst og fortolkninger [Violence against "gay" youth. Prevalences and interpretations]. Sosiologi i dag, 39(2), 43-71.

Steffens, M. C., \& Wagner, C. (2004). Attitudes towards lesbians, gay men, bisexual women, and bisexual men in Germany. Journal of Sex Research, 41(2), 137-149.

Swedish Official Report. (2001). Betânkande från Kommitteen om barn $i$ homosexuella familjer Proposals from the Committee on Children in Homosexual Families. Retrieved from http://www. sweden.gov.se/sb/d/135/a/608. 